\title{
ANALISIS PENERAPAN AKUNTANSI ASET TETAP PADA BADAN PENANGGULANGAN BENCANA DAERAH PROVINSI SULAWESI UTARA
}

\author{
Hendrykar Avaldo Regel ${ }^{1}$, Hendrik Manossoh ${ }^{2}$, Jessy D.L Warongan ${ }^{3}$ \\ ${ }^{1,2,3}$ Fakultas Ekonomi dan Bisnis, Jurusan Akuntansi, Universitas Sam Ratulangi, Jl.Kampus Bahu, Manado, \\ 95115, Indonesia \\ E-mail : aldoregel1996@gmail.com
}

\begin{abstract}
Regional Disaster Management Agency of North Sulawesi Province is an Instance that is in the scope of the Government of the City of Manado and carry out the policy areas in the field of disaster relief of the region. Fixed assets is the most important part in carrying out its operational activities. Fixed assets are tangible assets that have benefits over period of 12 (twelve) months for use in kegitan Government or utilized by the general public. This research aims to study how the application of fixed assets Accounting on Regional disaster management agency of North Sulawesi province. Data collection methods used are interviews and studies library. Data analysis method used is descriptive qualitative. The results of this research show that the application of fixed assets Accounting on Regional disaster management agency of North Sulawesi province have not everything works in accordance with Government accounting standards PP 71-year 2010. For the valuation of fixed assets not yet in compliance with the applicable policy. but for classification, recognition, measurement, termination and deletion, disclosure and shrinkage were in accordance with the applicable policy.
\end{abstract}

Keywords: Accounting, Fixed Assets, PSAP No.7

\section{PENDAHULUAN}

Reformasi politik yang terjadi di Indonesia telah mengubah sistem kehidupan bernegara yang dituntut oleh publik untuk lebih transparan dan akuntabel sehingga tercipta tata pemerintahan yang baik (good governance) yang bebas dari Korupsi, Kolusi, dan Nepotisme $(\mathrm{KKN})$ serta terjadi perimbangan antara pemerintah eksekutif, legislatif, dan yudikatif. Tata pemerintahan yang baik di sektor publik (good public governance) merupakan sistem atau aturan perilaku terkait dengan pengelolaan kewenangan oleh para penyelenggara negara dalam menjalankan tugasnya secara bertanggung jawab dan akuntabel. (Komite Nasional Kebijakan Governance, 2010)

Berdasarkan kedua undang-undang tersebut, akhirnya terbentuk Standar Akuntansi Pemerintahan (SAP) Peraturan Pemerintah (PP) No.24 Tahun 2005 berbasis kas menuju akrual (cash toward accrual). Selanjutnya pada Oktober 2010, pemerintah mengesahkan SAP berbasis akrual melalui PP No.71 Tahun 2010 menggantikan SAP PP No.24 Tahun 2005 berbasis kas menuju akrual.(SAP PP 71 No.07, 2010)

Pernyataan Standar Akuntansi Pemerintahan No. 07 adalah standar yang mengatur tentang asset tetap. Tujuan Pernyataan Standar ini adalah mengatur perlakuan akuntansi untuk asset tetap. yang di lihat dari pengakuan, pengukuran atau pengungkapan yang digunakan. Apakah akuntansi asset tetap yang dilaksanakan telah sesuai dengan standar yang ditetapkan pemerintah. Pemerintah daerah sebagai pihak yang menguasai aset daerah memiliki tanggung jawab dalam pengelolaan dan pemanfaatan aset daerah. Aset Tersebut berupa asset tetap yang digunakan pemerintah dalam menjalankan kegiatan operasionalnya. Seperti yang disebutkan dalam Pernyataan Standar Akuntansi Pemerintahan No. 07 tentang aset tetap bahwa, asset tetap merupakan aset berwujud yang mempunyai masa 
manfaat lebih dari 12 (dua belas) bulan dan tidak dapat di jual kembali untuk digunakan dalam kegiatan pemerintah atau dimanfaatkan oleh masyarakat umum. Aset tetap memiliki kontribusi yang berpengaruh besar dalam menjalankan tata kelola pemerintahan. Pengelolaan asset tetap yang tidak dilakukan dengan maksimal juga tidak dapat menunjang kegiatan pemerintah yang lebih efektif serta tidak dapat mewujudkan tujuan pemerintah yang baik. Pemerintah terutama dalam lingkup SKPD (Satuan Kerja Perangkat Daerah) memerlukan manajemen pengelolaan dalam memanfaatkan asset yang telah diperoleh, sehingga prinsip efisiensi, efektivitas, dan transparasi dapat terlaksana. Prinsip tersebut dapat berjalan baik dengan peraturan pemerintah yang telah ditetapkan Peraturan Pemerintah Nomor 71 tahun 2010 Lampiran II adalah peraturan Standar Akuntansi Pemerintahan yang mengatur standar akuntansi berbasis kas menuju akrual. (PSAP PP 71 No. 07, 2010)

Aset tetap merupakan salah satu bagian yang penting untuk menjalankan kegiatan operasi perusahaan. Tujuan utama dari usaha pemerintah merupakan memberikan pelayanan kepada masyarakat dengan sebaik-baiknya, dan asset tetap merupakan hal utama dalam memberikan pelayanan tersebut. Maka dapat dikatakan asset tetap menjadi sesuatu yang sangat penting pada sebuah instansi. Perusahaan merupakan organisasi modern yang mempunyai kegiatan tertentu untuk mencapai tujuan. Di lihat dari sisi perusahaan jasa, perusahaan dagang maupun perusahaan manufaktur. (Alfrianda, 2015: 8)

Perkembangan suatu usaha yang semakin maju perusahaan memerlukan suatu perlengkapan ataupun peralatan salah satunya yaitu aset tetap. Setiap perusahaan pasti memilki aset tetap, karena peranan aset tetap ini sangat besar dalam perusahaan. Aset tetap adalah aset yang dimiliki untuk dipakai, tidak untuk dijual kembali, umur pemakaian lebih dari satu tahun, Mempunyai manfaat bagi perusahaan yang dapat diukur, serta nilainya cukup berarti. Aset ini dapat digolongkan menjadi aset berwujud (tangible fixed assets) dan aset tak berwujud (intangible assets). (Alfrianda,2015: 8)

\section{TINJAUAN PUSTAKA}

\subsection{Akuntansi}

Akuntansi adalah suatu proses bahkan ilmu pencatatan, penggolongan, pengikhtisaran dan penyajian dengan cara-cara tertentu, transaksi keuangan yang terjadi dalam perusahaan atau organisasi lain serta penafsiran terhadap hasilnya" Mulyadi (2015:1) Akuntansi adalah suatu aktivitas jasa yang terdiri dari mencatat, mengklasifikasikan, dan melaporkan kejadian atau transaksi ekonomi yang akhirnya akan menghasilkan suatu informasi keuangan yang akan dibutuhkan oleh pihak-pihak tetentu untuk pengambilan keputusan (Sujarweni, 2015: 1)

\subsubsection{Akuntansi Keuangan}

Intermediate Accounting, Pengertian Akuntansi Keuangan adalah suatu rangkaian proses yang berujung pada penyusunan laporan keuangan yang berkaitan dengan perusahaan secara keseluruhan untuk di gunakan oleh pengguna laporan keuangan baik di dalam luar ataupun di luar perusahaan. ( Kieso dkk, $2010: 6$ )

\subsubsection{Akuntansi Biaya}

Satu satunya cabang akuntansi yang merupakan proses mengelola bahakan mengatur segala bentuk laporan akuntansi biaya bahkan alat manajemen dalam memonitor dan menekan transaksi biaya secara sistematis serta menyajikan informasi biaya dalam bentuk laporan biaya biasa di sebut dengan akuntansi biaya.(Nurlela, 2015: 1)

\subsubsection{Akuntansi Perpajakan}

Akuntansi perpajakan adalah suatu proses pencatatan bahkan perhitungan akuntansi untuk menentukan besarnya pajak yang harus dibayarkan oleh sebuah perusahaan dalam perhitungan kuantitatif yang dituliskan dalam sebuah laporan keuangan berkala. Laporan akuntansi perpajakan merupakan salah satu bagian dari laporan finansial yang mencatat semua pembayaran dan pemotongan yang harus dilakukan oleh sebuah perusahaan. 


\subsubsection{Akuntansi Anggaran}

suatu tekniks yang digunakan untuk mencatat bahkan melaporkan setiap transaksitransaksi yang terjadi dan terdapat pada setiap anggaran mulai dari anggaran bahkan proses identifikasi suatu anggaran yang terdapat dalam suatu laporan keuangan dalam perusahaan.

\subsubsection{Akuntansi Pemeriksaan}

Suatu identifkiasi, pemeriksaan untuk mendapatkan bahan bukti yang dilakukan secara kritis dan sistematis, oleh pihak yang independen, baik perusahaan jasa maupun dagang terhadap laporan keuangan yang telah disusun oleh manajemen, beserta catatancatatan pembukuan dan bukti-bukti pendukungnya, dg tujuan untuk dapat memberikan opini mengenai kewajaran laporan keuangan tersebut. (Sukrisno, 2016:10)

\subsubsection{Akuntansi Persediaan}

Definisi persediaan dalam akuntansi pemerintahan cukup dipengaruhi oleh karakteristik organisasi pemerintahan. Karakteristik pemerintahan dalam hal ini organisasi sektor publik berbeda dengan perusahaan. Sumber daya ekonomi organisasi sektor publik dikelola tidak untuk tujuan mencari laba (nirlaba). (Nordiawan, 2015:200).

\subsubsection{Akuntansi Pemerintahan}

Akuntansi Pemerintahan merupakan sistem yang mengatur proses akuntansi yang mengelola keuangan Negara (public finance) bahkan mengatur persediaan keuangan negara, khususnya pada tahapan pelaksanaan anggaran (budget execution), termasuk segala pengaruh yang ditimbulkannya dengan hasil pada pemerintahan.(Kustadi, 2015:1)

\subsection{Konsep Aset}

Aktiva atau Aset merupakan salah satu bagian dari kekayaan (sumber daya) bahkan harta yang dimiliki oleh setiap perusahaan bahkan entitas bisnis yang tidak dapat di uangkan atau tidak dapat di tukar kembali.

\subsection{Konsep Aset Tetap}

Aset tetap merupakan salah satu pos di neraca selain aset lancar, aset tak berwujud, aset bersejarah dan aset lainnya.

\subsection{Pernyataan Standar Akuntansi Pemerintahan No.07 Tahun 2010}

Pernyataan Standar Akuntansi Pemerintahan No.07 Tahun 2010 PP Nomor 71 Tahun 2010 tentang Standar Akuntansi Pemerintahan (SAP) menyatakan bahwa SAP adalah prinsipprinsip akuntansi yang diterapkan dalam menyusun dan menyajikan laporan keuangan pemerintah. PP 71 Tahun 2010 tentang Standar Akuntansi Pemerintahan terdapat 2 (dua) Lampiran yaitu: Lampiran I tentang Standar Akuntansi Pemerintahan Berbasis Akrual, Lampiran II tentang Standar Akuntansi Pemerintahan Berbasis Kas Menuju Akrual.

\section{METODE PENELITIAN}

\subsection{Jenis dan Sumber Data}

Secara umum, jenis data terbagi dua, yaitu data kualitatif dan kuantitatif. Jenis. Data kualitatif merupakan data yang disajikan secara deksriptif atau berbentuk uraian, sedangkan jenis data kuantitatif adalah data yang disajikan dalam bentuk angka-angka. Dalam penelitian ini, jenis data yang digunakan penulis adalah jenis data kualitatif yang bersifat deskriptif

\subsection{Teknik Pengumpulan Data}

Teknik yang penulis pakai dalam pengumpulan data adalah Dokumentasi, Wawancara, dan Studi Kepustakaan.

\subsection{Metode Analisis Data}

Analisis data merupakan tahapan penting dalam penelitian kualitatif. Analisis data merupakan suatu proses sistematis pencarian dan pengaturan transkip wawancara, obsevasi, catatan lapangan dokumen, foto, dan material lainnya untuk meningkatkan pemahaman peneliti tentang data yang telah dikumpulkan, sehingga memungkinkan temuan penelitian dapat di sajikan dan di informasikan kepada orang lain. yang bertujuan untuk 
menggambarkan dan menerangkan fenomena atau situasi sosial yang diteliti.

\section{HASIL PENELITIAN DAN PEMBAHASAN \\ 4.1 Hasil Penelitian \\ 4.1.1 Klasifikasi Aset Tetap}

Aset tetap pada Badan Penanggulangan Bencana Daerah Provinsi Sulawesi Utara diklasifikasikan berdasarkan kesamaan dalam sifat atau fungsinya dalam aktivitas operasi entitas yang terdiri dari :

KIB A : Tanah

KIB B : Peralatan dan Mesin

KIB C : Bangunan dan Gedung

\subsubsection{Pengakuan Aset Tetap}

Aset pada Badan Penanggulangan Bencana Daerah Provinsi Sulawesi Utara diakui sebagai aset tetap jika aset tersebut mempunyai masa manfaat lebih dari 12 (dua belas) bulan, biaya perolehan dapat diukur secara andal, tidak untuk dijual, dan diperoleh untuk digunakan.

\subsubsection{Pengukuran Aset Tetap}

Biaya perolehan tidak memungkinkan maka nilai aset tetap didasarkan pada nilai wajar pada saat perolehan. Biaya perolehan aset tetap Badan Penanggulangan Bencana Daerah Provinsi Sulawesi Utara terdiri dari keseluruhan biaya yang dikeluarkan untuk perolehan aset tetap sampai siap pakai, tetapi untuk tanah, gedung dan bangunan diukur dengan nilai penyerahan aset tetap tersebut ke pihak Badan Penanggulangan Bencana Daerah Provinsi Sulawesi Utara.

\subsubsection{Penilaian Aset Tetap}

Penilaian aset tetap pada Badan Penanggulangan Bencana Daerah Provinsi Sulawesi Utara dilakukan dalam penyusunan neraca, namun penilaian aset tetap pada Badan Penanggulangan Bencana Daerah Provinsi Sulawesi Utara hanya memakai penilai dari pegawai pada bagian umum bidang aset tetap dan belum memakai penilai independen yang bersertifikat di bidang penilaian aset sehingga masih terdapat aset yang dianggap hilang yang tidak tercatat pada daftar aset Badan Penanggulangan Bencana Daerah Provinsi Sulawesi Utara. Hal ini dibuktikan dengan adanya nama barang pada KIB tetapi tidak tercatat nominal dari harga barang tersebut.

\subsubsection{Penghentian dan Pelepasan Aset Tetap}

Aset tetap akan dilepaskan atau dihapuskan jika sudah tidak bisa mendatangkan manfaat bagi Badan Penanggulangan Bencana Daerah Provinsi Sulawesi Utara. Penghapusan meliputi penghapusan dari daftar pengguna dan atau kuasa penganggaran, dan penghapusan dari daftar Barang Milik Daerah. Berdasarkan hasil wawancara dengan Pengurus Barang Badan Penanggulangan Bencana Daerah Provinsi Sulawesi Utara.

\subsubsection{Pengungkapan Aset Tetap}

Badan Penanggulangan Bencana Daerah Provinsi Sulawesi Utara mengungkapkan kebijakan akuntansi yang berlaku serta informasi mengenai pos-pos aset tetap dalam Catatan atas Laporan Keuangan (CaLK).Pengungkapan ini sangat penting sebagai penjelasan tentang hal-hal penting yang tercantum dalam neraca. Tujuan pengungkapan ini adalah untuk meminimalisasi kesalahan persepsi bagi pembaca laporan keuangan.

\subsubsection{Penyusutan Aset Tetap}

Metode penyusutan yang digunakan oleh adalah Metode Garis Lurus (Straight Line Method). Metode ini adalah metode penyusutan dimana besarnya penyusutan selalu sama dari tiap periode akuntansi selama umur ekonomis dari aset tetap yang bersangkutan. Berdasarkan penjelasan dari Pengurus Barang SKPD Badan Penanggulangan Bencana Daerah Provinsi Sulawesi Utara. 


\subsection{Pembahasan}

\subsubsection{Klasifikasi Aset Tetap}

Aset Tetap pada Badan Penanggulangan Bencana Daerah Provinsi Sulawesi Utara digolongkan berdasarkan kesamaan sifat atau fungsinya dalam aktivitas operasi yaitu (1) tanah: mencakup tanah yang digunakan sebagai gedung kantor dan rumah dinas (2) peralatan dan mesin: alat perkantoran, komputer, meja dan kursi, lemari, mobil dinas (ambulance, pemadam kebakaran), motor dinas, perahu (3) gedung dan bangunan: mencakup gedung tempat kerja dan gedung tempat tinggal dan dalam kondisi siap pakai. Aset tetap tersebut di gunakan untuk aktivitas pemerintah dan pelayanan publik.

\subsubsection{Pengakuan Aset Tetap}

Aset tetap diakui pada saat manfaat ekonomi masa depan dapat diperoleh dan nilainya dapat diukur dengan handal. Biaya perolehan aset dapat diukur secara handal, Tidak dimaksutkan untuk dijual dalam operasi normal entitas, Diperoleh/dibangun dengan maksud untuk digunakan.Perolehan peralatan dapat melalui pembelian, pembangunan, atau pertukaran aset, hibah/donasi, dan lainnya.Perolehan melalui pembelian dapat dilakukan dengan pembelian tunai dan angsuran.

\subsubsection{Pengukuran Aset Tetap}

Aset tetap dinilai dengan biaya perolehan. yang dimiliki atau yang di kuasasi atauoleh pemerintah harus dinilai atau diukur untuk dapat dilaporkan dalam neraca. Menurut SAP, aset tetap yang diperoleh atau dibangun secara swakelola dinilai dengan biaya perolehan.aset tetap menggunakan biaya perolehan tidak memungkinkan maka nilai aset tetap didasarkan pada nilai wajar pada saat perolehan.

\subsubsection{Penilaian Aset Tetap}

1. Penilaian Awal : Barang berwujud yang memenuhi kualifikasi untuk diakui sebagai suatu aset dan dikelompokan sebagai aset tetap, pada awalnya harus diukur berdasarkan biaya perolehan.

2. Penilaian Kembali : Kebijakan umum akuntansi aset tetap dalam SAP adalah pencatatan dilakukan dalam nilai perolehannya, namun ketika akan dilakukan revaluasi maka harus diatur dalam peraturan yang berlaku secara nasional. Jika aset tetap dicatat pada jumlah yang dinilai kembali, hal-hal yang harus diungkapkan antara lain sebagai berikut. Dasar peraturan untuk menilai kembali aset tetap, tanggal efektif penilaian kembali, nama penilai independen (Tim Khusus Penilai), hakikat setiap petunjuk yang digunakan untuk menentukan biaya pengganti, Nilai tercatat setiap jenis aset tetap.

\subsubsection{Penghentian dan Penghapusan Aset Tetap}

Penghentian dan Penghapusan Aset Tetap Suatu aset tetap dihapuskan dari neraca ketika dilepaskan atau bila aset tetap secara permanen dihentikan penggunaannya dan tidak ada manfaat ekonomis masa yang akan datang diungkapkan dalam Catatan atas Laporan Keuangan (CaLK).

\subsubsection{Pengungkapan Aset Tetap}

Pengungkapkan Selain disajikan pada lembar muka neraca, aset tetap juga harus diungkapkan dalam Catatan atas Laporan Keuangan (CaLK). Pengungkapan ini sangat penting sebagai penjelasan tentang hal hal penting yang tercantum dalam neraca. Tujuan pengungkapan ini adalah untuk meminimalisasi kesalahan presepsi bagi pembaca laporan. Pengungkapan aset tetap oleh Badan Penanggulangan Bencana Daerah Provinsi Sulawesi Utara telah sesuai dengan peraturan pemerintah yang berlaku yaitu Peraturan Pemerintah No. 71 Tahun tentang PSAP No. 07 tentang akuntansi aset tetap.

\subsubsection{Penyusutan Aset Tetap}

Faktor penentu penyusutan terkait dengan penyusutan aset tetap, terdapat tiga faktor yang harus diperhitungkan dalam menentukan jumlah beban penyusutan aset tetap. 
Harga perolehan aset tetap harga perolehan yaitu sejumlah uang yang dikeluarkan dalam memperoleh aktiva tetap hingga siap digunakan, Masa manfaat yang diharapkan, Perkiraan nilai aset tetap pada akhir masa manfaat (nilai residu atau nilai sisa), Nilai sisa atau nilai residu adalah jumlah yang diperkirakan dapat direalisasikan pada saat aktiva tidak digunakan lagi.

\section{KESIMPULAN DAN SARAN}

\subsection{Kesimpulan}

Berdasarkan hasil penelitian dan pembahasan yang dilakukan dalam menganalisis penerapan Pernyataan Standar Akuntansi Pemerintahan (PSAP) No. 07 tentang akuntansi aset tetap pada Badan Penanggulangan Bencana Daerah Provinsi Sulawesi Utara, maka dapat diambil kesimpulan sebagai berikut:

1. Pengklasifikasian aset tetap pada Badan Penanggulangan Bencana Daerah Provinsi Sulawesi Utara sudah sesuai dengan PSAP No. 07 yaitu diklasifikasikan berdasarkan sifat dan fungsinya yang terdiri dari tanah, peralatan dan mesin, gedung dan bangunan, Pengakuan kepemilikan aset tetap pada BPBD Provinsi Sulawesi Utara sudah sesuai dengan PSAP No. 07 yaitu ketika diterima/diserahkan hak kepemilikan aset tetap dan ditandai dengan berita acara serah terima aset tetap ke pihak BPBD Provinsi Sulawesi Utara.

2. Pengakuan aset tetap oleh Badan Penanggulangan Bencana Daerah Provinsi Sulawesi Utara telah sesuai dengan peraturan pemerintah yang berlaku yaitu Peraturan Pemerintah No. 71 Tahun 2010 Pernyataan Standar Akuntansi Pemerintahan (PSAP) No. 07 tentang akuntansi aset tetap.

3. Pengukuran aset tetap pada Badan Penanggulangan Bencana Daerah Provinsi Sulawesi Utara sudah sesuai dengan PSAP No. 07 yaitu dengan menggunakan biaya perolehan.

4. Penilaian aset tetap pada Badan Penanggulangan Bencana Daerah Provinsi Sulawesi Utara dilakukan dalam penyusunan neraca, namun untuk penilaian aset tetap pada Badan Penanggulangan Bencana Daerah Provinsi Sulawesi Utara hanya memakai penilai dari pegawai pada bagian umum bidang aset tetap dan belum memakai penilai independen yang bersertifikat di bidang penilaian aset sehingga masih terdapat aset yang dianggap hilang yang tidak tercatat pada daftar aset Badan Penanggulangan Bencana Daerah Provinsi Sulawesi Utara.

5. Penghentian dan Pelepasan aset tetap pada Badan Penanggulangan Bencana Daerah Provinsi Sulawesi Utara sudah sesuai dengan PSAP No. 07 yaitu jika terdapat aset tetap yang rusak maka akan mengajukan surat penghapusan ke Pemerintah Daerah, kemudian setelah disetujui maka aset tetap tersebut dieliminasi dari laporan keuangan.

6. Pengungkapan aset tetap Badan Penanggulangan Bencana Daerah Provinsi Sulawesi Utara pada Catatan atas Laporan Keuangan sudah sesuai dengan PSAP No. 07 yaitu mengungkapkan dasar penilaian yang digunakan untuk menentukan nilai tercatat dalam laporan keuangan, informasi penyusutan, hingga kebijakan akuntansi kapitalisasi yang berkaitan dengan aset tetap.

7. Penyusutan pada Badan Penanggulangan Bencana Daerah Provinsi Sulawesi Utara: akumulasi penyusutan tersebut sebenarnya tidak dikelola sendiri oleh pihak Badan Penanggulangan Bencana Daerah Provinsi Sulawesi Utara melainkan hanya memakai aplikasi SIMDA dari Badan Pengelola Keuangan dan Barang Milik Daerah (BPKBMD) Sulawesi Utara sehingga nilai akumulasi penyusutan yang ada dikelola oleh BPK-BMD. 


\subsection{Saran}

Berdasarkan hasil penelitian dan pembahasan yang dilakukan dalam menganalisis penerapan PSAP No. 07 tentang akuntansi aset tetap BPBD Provinsi Sulawesi Utara, Saran yang dapat diberikan dalam penelitian ini:

1. Untuk Penilaian aset tetap pada BPBD Provinsi Sulawesi Utara, seharusnya menggunakan tim khusus baik dari daerah maupun pusat (Tim Independen)

2. Penelitian mendatang memperbanyak informan dalam penelitian agar lebih baik lagi kedepan.

\section{DAFTAR PUSTAKA}

Auliana. 2010. Analisis Akuntansi Aset Tetap Pada Badan Penanggulangan Bencana Daerah Kota Tanjung Pinang. Jurnal.Universitas Maritim Raja Ali Haji, Tanjungpinang, Vol 3, No.3, hlm. 117-131.

Alfrianda. 2015. Akuntansi, Standar Akuntansi Pemerintahan, Pengertian Aset. Edisi 8. Salemba Empat. Jakarta.

Ikatan Akuntansi Indonesia.2015. Standar Akuntansi Keuangan Pemerintahan. Jakarta : Salemba Empat.

Kieso, dkk. 2010. Akuntansi. Intermediate Accounting. Edisi Pertama. Jakarta.

Mulyadi. 2015. Pengertian Akuntansi menurut para ahli. Edisi Pertama. Salemba Empat. Jakarta.

Peraturan Pemerintah Republik Indonesia Nomor 71 tahun 2010 Lampiran II Tentang Standar Akuntansi Pemerintahan.

Pemerintah Republik Indonesia, 2010. Peraturan Pemerintah Nomor 71 Tahun2010 Pernyataan No.7 tentang Standar Akuntansi Berbasis Akrual.

Peraturan Menteri dalam Negeri Nomor 21. 2011. Perubahan Kedua atas Peraturan Menteri dalam Negeri. Nomor 13 Tahun. 2006. Pedoman Pengelolaan Keuangan Daerah.

Peraturan Menteri Dalam Negeri Nomor 64. 2013. Penerapan Standar Akuntansi Pemerintahan Berbasis Akrual pada Pemerintah Daerah.

Peraturan Pemerintah Nomor 58. 2005. Pengelolaan Keuangan Daerah.

Peraturan Pemerintah Republik Indonesia Nomor 71. 2010 Lampiran I Standar Akuntansi Pemerintahan Berbasis Akrual Pernyataan Nomor 5 tentang Akuntansi Persediaan dan Pernyataan Nomor 7 tentang Akuntansi Aset Tetap.

Peraturan Pemerintah Republik Indonesia No.27 Tahun 2014. Pengelolaan Barang Milik Negara/Daerah.

Revrisond, Baswir. 2013. Akuntansi. Akuntansi Pemerintahan. Edisi Pertama. Salemba Empat. Jakarta.

Sukrisno, Agus. 2016. Akuntansi. Akuntansi Pemerikasaan. Edisi Pertama. hlm: 10. Salemba Empat. Jakarta. 